\title{
Comparative stem and petiole anatomy of West African species of Momordica L (Cucurbitaceae)
}

\author{
C. U. Aguoru ${ }^{1 *}$ and B. E. Okoli ${ }^{2}$ \\ ${ }^{1}$ Department of Biological Sciences, University of Agriculture Makurdi, Nigeria. \\ ${ }^{2}$ Department of Plant Science and Biotechnology, University of Port Harcourt, Nigeria.
}

Accepted 23 August 2012

\begin{abstract}
Petiole and stem gross anatomy of seven West African species of Momordica $L$ of the family Cucurbitaceae were studied. This was with a view to exploiting their systematic and taxonomic significance; this is because other studies on them were based on morphology. Representatives of the five species were obtained from various parts of the West African sub-region and passed through standard treatments to make permanent anatomical slides for the study. Micrographic evidences of distinguishing and affinity taxonomic features were made. Variations in petiole and stem anatomical attributes were obvious that they could be used as systematic evidence to taxonomically delineate these taxa even at species level. The evidences are used to locate the species in the tribe Cucurbitoideae. The occurrence of grit cells below the epidermis of the petiole of Momordica cabraei is remarkable and separates it from others; this is reported for the first time. Whereas in Momordica cissoides, brachysclerids are found interspersing the cells of the epidermal layer of the petiole which is also reported for the first time. Both stem and petiolar vascular bundle quantitatively separates the species. Cortical parenchyma cellular layers differentiates the species and therefore delineated them. Momordica balsamina stands apart with the possession of stemic 15 to 17 cellular layers of sclerenchymatous tissues. In $M$. cabraei, the grit cells are present in stem where it is scattered across the tissues whereas in Momordica multiflora, where it was lacking in petiole, packs are arranged below stemic epidermal tissues. The occurrence of starch deposit across various tissue layers of $\boldsymbol{M}$. multiflora petiole also stands it out. Various other distinguishing features are discussed. The use of petiolar and stemic anatomical features in systematic description of Momordica species is maiden and innovative and reported for the first time.
\end{abstract}

Key words: Momordica, Cucurbitaceae, stem, petiole, systematics, taxonomy, cucurbitoideae.

\section{INTRODUCTION}

Momordica $L$ is of the tribe Joliffia in the family Cucurbitaceae, sub-family Cucurbitoidea (Jeffrey, 1964, 1980). The genus is represented in West Africa by seven species (Hutchinson and Dalziel, 1954). Momordica like other Cucurbits are frost sensitive and therefore, confined to warmer parts of the globe (Tsuchiya and Gupta, 1991, Uno et al., 2001). The genus share cucurbits common characteristics (Purseglove, 1968). Momordica is recognisable in the field with such obvious features as

\footnotetext{
${ }^{*}$ Corresponding author. E-mail: celeaguoru@yahoo.com.
}

coarse tendrils usually extra-axillary, bearing vines with unisexual flowers often yellowish or white with inferior and leathery berries/pepo (Ndukwu, 1988; Aguoru and Okoli, 2008). The stems are herbaceous, angular hollow, climbing by means of tendrils (Gill, 1988). Momordica species are plants with enormous potential as source of food and drug (Aguoru and Ogaba, 2010); they are associated with varied ethno-botanical uses and occupy special place in the lives and activities of many West African tribes (Aguoru and Okoli, 2008; Burkill, 1985; Okoli, 1984; Dalziel, 1937; Aguoru and Ogaba, 2010). Various studies on Momordica have been based more on morphological features (Aguoru and Okoli, 2008). The 
use of plant anatomy (internal structures) in the elucidation of taxonomic and systematic relationships is not new and has been reported (Edeoga and Okoli, 1997, 2001; Mbagwu and Edeoga, 2006; Nwachukwu and Mbagwu, 2007; Vaughan, 1970; Singh and Dattan, 1980; Ndukwu, 1988; Esau, 1965; Metcalfe and Chalk, 1979). Despite the availability of these studies, no investigation has been conducted on not just the taxonomic usefulness of the stem and petiole anatomy of Momordica species but on the entire anatomy of the two organs of the Momordica species. This paper therefore reports for the first time the basic anatomical features of the stem and petiole of the West African species of Momordica which are also of systematic and taxonomic values.

\section{MATERIALS AND METHODS}

Representatives of the seven species were obtained from various parts of the West African sub-region and passed through standard treatments to make permanent anatomical slides for the study. Mature fresh and hot water revived dry stems and petioles were used for the study. The materials were fixed in FAA $(1: 1: 8,40 \%$ formaldehyde : glacial acetic acid : $70 \%$ ethyl alcohol $\mathrm{v} / \mathrm{v}$ ) for at least $48 \mathrm{~h}$. The tissues which had been so fixed were later used for section preparation following the method of Aguoru and Okoli (2008) with modifications. The stem and petiole tissues were rinsed in several changes of distilled water, placed in glass vials and dehydrated through alcohol series $(30,50,70,95$ and $100 \%)$ for $2 \mathrm{~h}$ in each. The dehydrated tissues were infiltrated with wax by passing them through different proportions of alcohol and chloroform $(3: 1,1: 1$, and $1: 3) \mathrm{v} / \mathrm{v}$ for $3 \mathrm{~h}$ in each. As the chloroform gradually replaced, the alcohol, pure chloroform and wax were put in the vials containing the tissues. This was to gradually infiltrate the tissue with wax, which would make them hard enough for microtomy.

The vials were left on a hot plate $\left(37\right.$ to $\left.40^{\circ} \mathrm{C}\right)$ for $24 \mathrm{~h}$ before being transferred to oven $\left(60\right.$ to $\left.65^{\circ} \mathrm{C}\right)$. This was meant to evaporate the chloroform and facilitate the complete infiltration of the tissues with wax. After a period of $72 \mathrm{~h}$ with constant addition of wax, the tissues were embedded in paraffin wax by use of metal moulds and molten wax. This was accomplished by a quick orientation of the plant materials in mould with a hot mounted needle and forceps, and cooling in iced-water later. The moulds were later removed and the "wax-cubed" containing the tissues were trimmed and sectioned using a Shandon microtome at 15 to $20 \mu \mathrm{m}$. The section in wax ribbon was collected on slides already smeared with egg albumen. The slides were placed on hot plate at $40^{\circ} \mathrm{C}$ for $4 \mathrm{~min}$ to enable the ribbons expand and kept in an oven at $40^{\circ} \mathrm{C}$ till required. The sections were de-waxed in pure xylene and rehydrated in alcohol series in the order of 100, 95, 70, 50 and 30\% for a few minutes in each. Staining was achieved by placing drops of $1 \%$ safranin on the sections for about $2 \mathrm{~min}$, washed of with distilled water and counter stained with $1 \%$ safranin for $2 \mathrm{~min}$. The stain was washed off with distilled water and sections dehydrated through alcohol series starting from 50, 70, 95 and $100 \%$ for a few minutes in each. Clearing was done with xylene and mounted in Canada balsam. The slides so prepared were dried on a hot plate at $30^{\circ} \mathrm{C}$. A minimum of 30 anatomical sections made from specimens obtained from various different locations were viewed to establish number of cell layers that constitute each tissue section and number of vascular bundles for each species. Photomicrographs were taken using a Leitz Wetzlar Ortholut Microscope fitted with Vivita camera from best anatomical sections.

\section{RESULTS}

The comparative anatomical features of the petioles and stems of the seven species of Momordica found in West Africa are summarised in Table 1 and displayed in the Figures 1 and 2. The petiole of Momordica charantia shows a piliferous, single layered epidermis made up of oval shaped cells closely followed by two layers of collenchymatous cells and seven layers of sclerenchyma cells, 10 bicollateral vascular bundles, which appears thicker on the outer portion. The hypodermal cells are oval shaped; the petiole has a pith. Momordica cissoids petiole epidermal cells are single layered having grit cells at regular intervals, one to two layers of collenchyma cells and three to four layers of sclerenchyma cells. The vascular bundles are eight in number and there is the presence of pith. Momordica multiflora petiole has a single layered epidermal cell, one to two layers of collenchymatous cells and four to five layers of sclerenchyma cell with 18 number vascular bundles. There is the presence of pith which is non-septate. Momordica cabraei petiole epidermis is single layered, below it occurs a double layered grit cells, four to six layers of sclerenchyma and one to two layers of parenchyma. 10 number bicollateral vascular bundles and two to three layers of grit cells surround the vascular bundles especially around the ridges; pith is absent. Momordica foetida petiole epidermis is piliferous and single layered, sclerenchyma cells three to four layers with a single layer of parenchyma which are elongated, with 10 bicollateral vascular bundles and non septate pith. Momordica angustisepala petiole has single layered epidermis followed by a single layered collenchymatous cells and four to seven layers of Sclerenchymatous cells having thickened walls. 18 number bicollateral vascular bundles; pith is present. Momordica basalmina petiole is winged, covered with single layered epidermis, two to three layers of collenchyma and about three layers of Sclerenchymatous cells. Six number bicollateral vascular bundles; pith is absent. The stem of Momordica charantia like the petiole has an oval shape, single cell layered piliferous epidermis, four to five cell layers of collenchyma and five to six layers of sclerenchyma cells, 10 bicollateral vascular bundles and a hollow cylinder. Momordica cissiodes stem has single cell layered epidermal cells, around the ridges five to six layers of sclerenchyma cells around the furrows directly below the epidermis eight to 10 layers of collenchyma, two to three layers of sclerenchyma and single layer of parenchymatous cells surrounding 12 bicollateral vascular bundles. In Momordica multifloram, stems have furrows and ridges. The epidermis on the ridges are single layered and directly below it is a single layer of brachysclerids (grit cells) six to seven layers of sclerenchyma and same number of layers of parenchyma. On the furrows, epidermal cell layers are two followed by two to three layers of collenchymatous cells before a single layer of sclerenchyma cells. The 
Table 1. Summary of the anatomical features of the Petiole and stem of the Momordica species studied.

\begin{tabular}{|c|c|c|c|c|c|c|c|c|}
\hline \multirow{2}{*}{ Plant part } & \multirow[b]{2}{*}{ Features } & \multicolumn{7}{|c|}{ Momordica species } \\
\hline & & M. charantia & M. cabrae & M. cissoides & M. foetida & M. multiflora & M. angustisepala & M. balsamina \\
\hline \multirow{6}{*}{ Petiole } & $\begin{array}{l}\text { Nature of } \\
\text { epidermis }\end{array}$ & $\begin{array}{l}\text { Piliferous oval } \\
\text { shaped albumen }\end{array}$ & Single layer & $\begin{array}{l}\text { Single layer } \\
\text { non-piliferous }\end{array}$ & $\begin{array}{l}\text { Single layer and } \\
\text { piliferous }\end{array}$ & Single layer & Single layer & Single layer \\
\hline & Sclerenchyma & 1-7 layers & 4-6 cell layers & 3-4 layers & 3-4 layers & 4-5 layers & 4-7 layers & 3 layers \\
\hline & Parenchyma & Absent & 1-2 layers & Absent & $\begin{array}{l}\text { Elongated } \\
1-2 \text { layers }\end{array}$ & Absent & Absent & Absent \\
\hline & $\begin{array}{l}\text { Collenchyma cell } \\
\text { layer thickness }\end{array}$ & 2 cell layers thick & Absent & 1-2 layers thick & Absent & 1-2 layers & Single layer & 2-3 layers \\
\hline & $\begin{array}{l}\text { Number of } \\
\text { vascular bundles }\end{array}$ & $\begin{array}{l}10 \text { bi-collateral } \\
\text { vascular bundle }\end{array}$ & $\begin{array}{l}10 \text { bi-collateral } \\
\text { vascular bundle }\end{array}$ & $\begin{array}{l}8 \text { bi-collateral } \\
\text { vascular bundle }\end{array}$ & $\begin{array}{l}10 \text { bi-collateral } \\
\text { vascular bundle }\end{array}$ & $\begin{array}{l}18 \text { bi-collateral } \\
\text { vascular bundle }\end{array}$ & $\begin{array}{l}18 \text { bi-collateral } \\
\text { vascular bundle }\end{array}$ & $\begin{array}{l}6 \text { bi-collateral } \\
\text { vascular bundle }\end{array}$ \\
\hline & $\begin{array}{l}\text { Other } \\
\text { distinguishing } \\
\text { features of each } \\
\text { species }\end{array}$ & $\begin{array}{l}\text { Pith present with } \\
\text { septum }\end{array}$ & $\begin{array}{l}2 \text { grit cell layers } \\
\text { under epidermis }\end{array}$ & $\begin{array}{l}\text { Grit cells } \\
\text { interspersed } \\
\text { epidermis }\end{array}$ & Pith present & $\begin{array}{l}\text { Starch deposits } \\
\text { at various tissue } \\
\text { layers }\end{array}$ & $\begin{array}{l}\text { Pith present } \\
\text { without septum }\end{array}$ & Winged \\
\hline \multirow{5}{*}{ Stem } & Collenchyma & 4-5 layers & Absent & 8-10 layers & 2-3 layers & $\begin{array}{l}2-3 \text { layers on } \\
\text { furrows only }\end{array}$ & Absent & Absent \\
\hline & $\begin{array}{l}\text { Cortical } \\
\text { parenchyma }\end{array}$ & 4 cell layers thick & 6-8 layers thick & Single layers & 2-3 layers & 6-7 layers & Absent & Absent \\
\hline & $\begin{array}{l}\text { Sclerenchyma } \\
\text { layer thickness }\end{array}$ & 6 layers thick & 6-7 layers thick & 2-3 layers & 6-7 layers & 6-7 layers & 8-9 layers & $\begin{array}{l}15-17 \text { layers } \\
\text { with very thick } \\
\text { walls }\end{array}$ \\
\hline & $\begin{array}{l}\text { Number of } \\
\text { vascular bundle }\end{array}$ & $\begin{array}{l}10 \text { bi-collateral } \\
\text { vascular bundle }\end{array}$ & $\begin{array}{l}10 \text { bi-collateral } \\
\text { vascular bundle }\end{array}$ & $\begin{array}{l}12 \text { bi-collateral } \\
\text { vascular bundle }\end{array}$ & $\begin{array}{l}12 \text { bi-collateral } \\
\text { vascular bundle }\end{array}$ & $\begin{array}{l}20 \text { vascular } \\
\text { bundle with } \\
\text { special sieve } \\
\text { tubes present }\end{array}$ & $\begin{array}{l}11 \text { bi-collateral } \\
\text { vascular bundle }\end{array}$ & $\begin{array}{l}18 \text { bi-collateral } \\
\text { vascular bundle } \\
\text { with circular } \\
\text { cylinder carrying } \\
\text { thick walls. }\end{array}$ \\
\hline & $\begin{array}{l}\text { Other } \\
\text { distinguishing } \\
\text { features species } \\
\text { each studied }\end{array}$ & Hollow cylinder & $\begin{array}{l}\text { Brachysclerids } \\
\text { scattered }\end{array}$ & $\begin{array}{l}\text { On the ridges } \\
\text { sclerenchyma is } \\
5-6 \text { layers }\end{array}$ & Pith present & $\begin{array}{l}\text { Grit cells directly } \\
\text { below epidermis } \\
\text { on ridge }\end{array}$ & $\begin{array}{l}\text { Pith present with } \\
\text { septum }\end{array}$ & $\begin{array}{l}\text { Circular cylinder } \\
\text { walls around the } \\
\text { ridges are } \\
\text { thickened }\end{array}$ \\
\hline
\end{tabular}




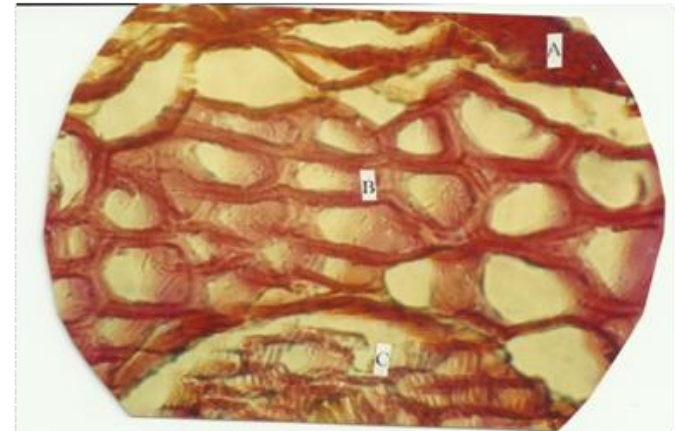

M. angustisepala

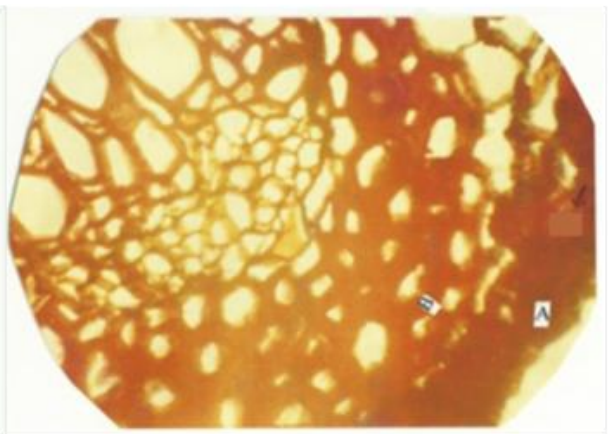

M. cossoides
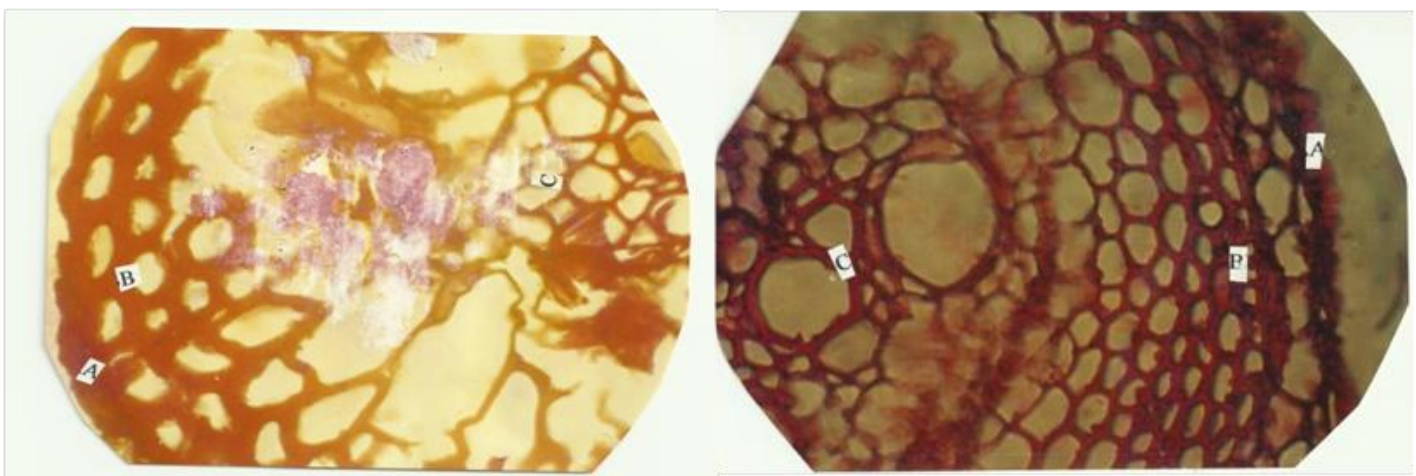

M. foetida

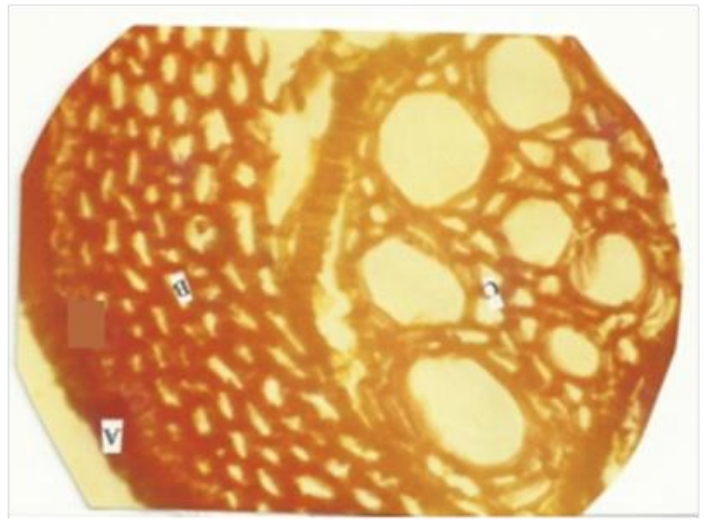

M. cabraei
M. charantia

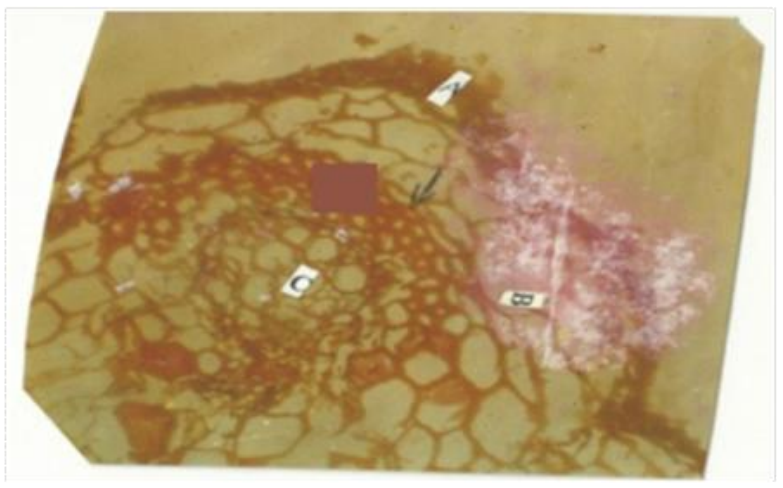

M. multiflora

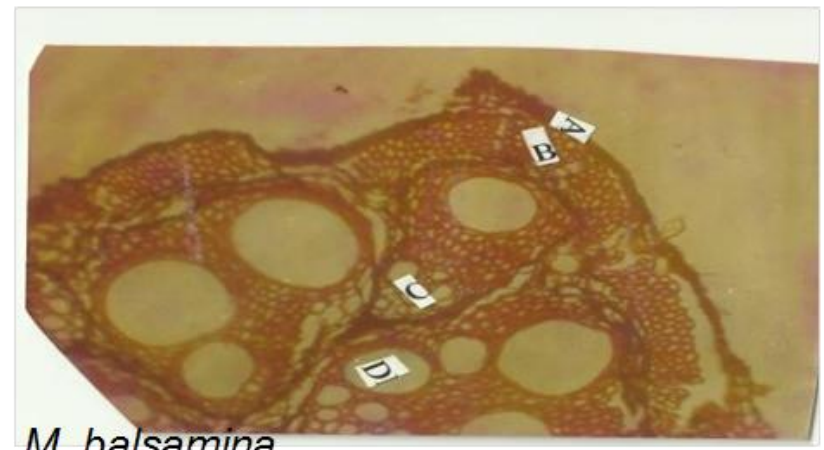

M. balsamina

Figure 1. Petioles of the various Momordica species studied. A, Epidermis; B, cortex; C, vascular bundle; D, grit/stone cells (Brachysclereids). 


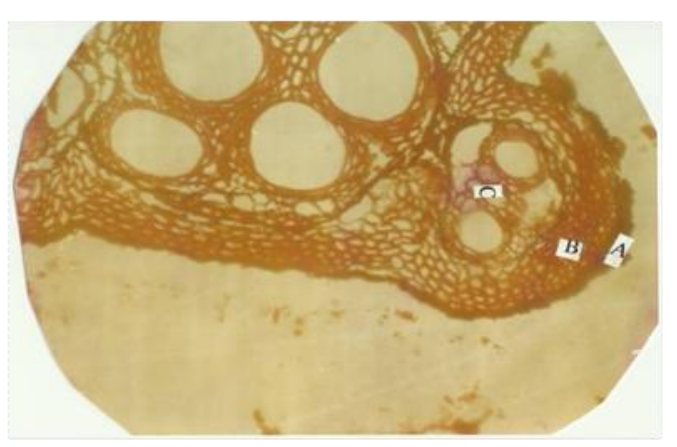

M. cissoides (a)

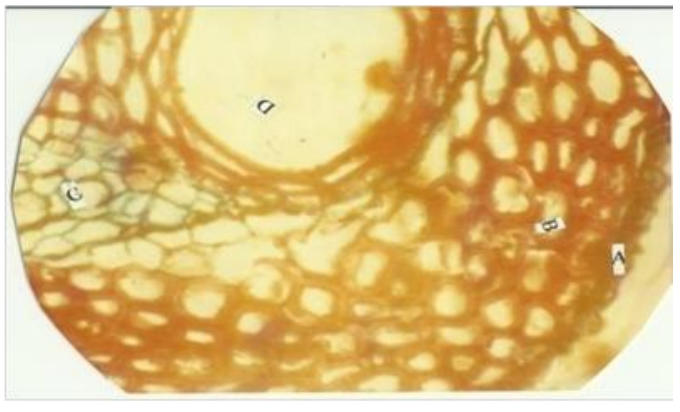

M. cissoides (b)

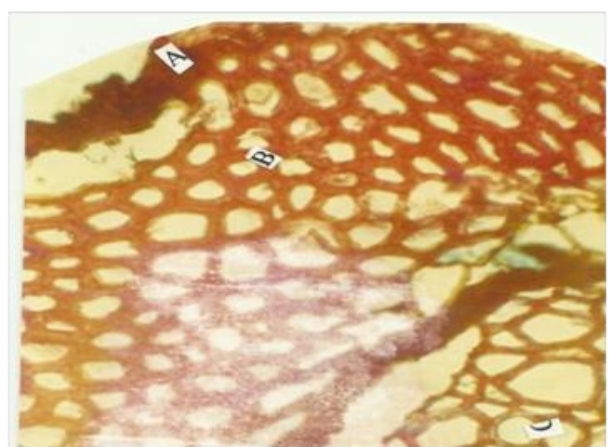

M. angustisepala

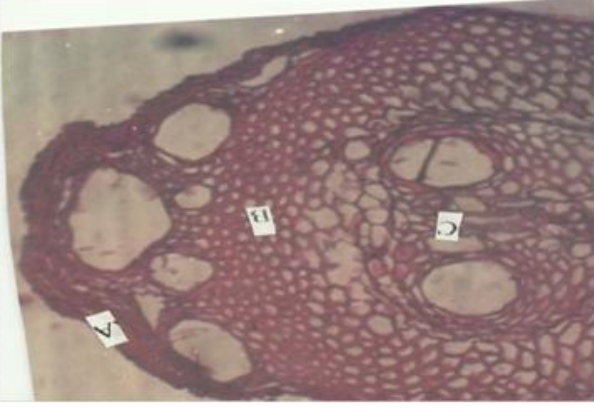

M. foetida

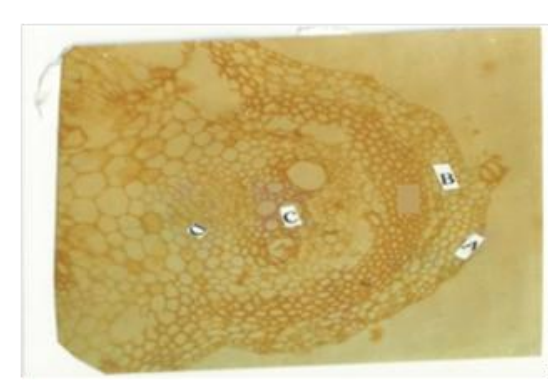

M. charantia

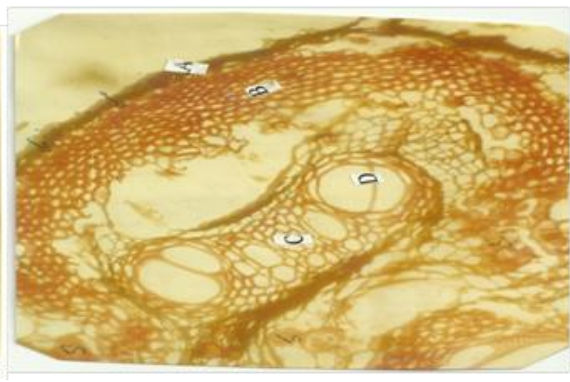

M. multiflora

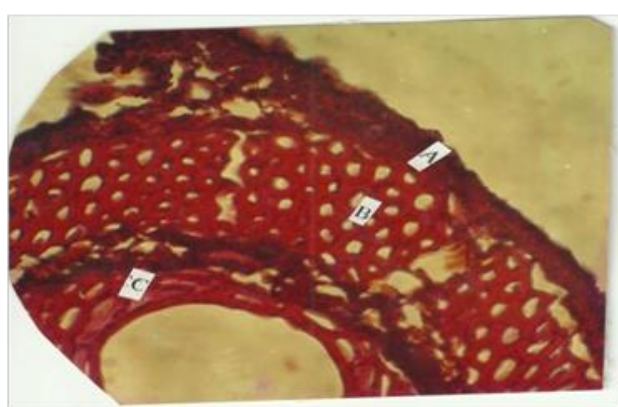

M. balsamina

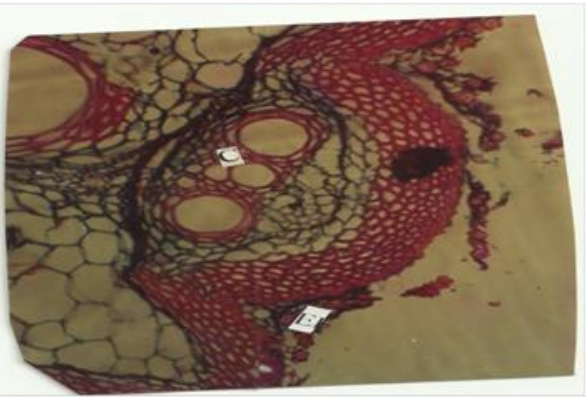

M. cabraei

Figure 2. Stems of the various Momordica species studied. A, Epidermis; B, cortex; C, vascular bundle; $\mathrm{D}$, grit/stone cells (Brachysclereeds).

stem possesses 20 numbers of vascular bundles with special sieve tubes. The stem of $M$. cabraei has a single layer of outer epidermis which is one cell layer thick and covered by a thin cuticle, below the epidermis are two to 
three layers of brachysclerids followed by six to seven layers of sclerenchyma cells and six to eight layers of parenchyma, two bicollateral vascular bundle and circular central pith. There is the presence of stellar Sclerenchymatous bundle sheath reinforcement of the vascular bundle. $M$. foetida has a single layered piliferous epidermis, two to three layers of collenchyma, six to seven layers of sclerenchyma and two to three layers of parenchyma, 12 bicollateral vascular bundle; pith is present but with a septum. On the ridges, there are wing like structures which carry three to four circular holes in them and there is a mixture of collenchyma and parenchyma. $M$. angustisepala stem carries a single layer epidermis without cuticle, eight to nine layers of sclerenchyma and 16 bicollateral vascular bundle; the other cell layers are missing; pith is present. The stem of $M$. balsamina is covered with single layer of epidermal cells and cuticularised. 15-17 layers of sclerenchyma cells are with highly thickened walls, and18 bicollateral vascular bundles with a broad circular cylinder. The cylinders are reinforced by thick walls especially on the ridges.

\section{DISCUSSION}

Anatomical evidences have been exploited in delimiting taxa (Metcalfe and Chalk, 1979; Aguoru and Okoli, 2008c). The petiole and stem anatomy of the Momordica species showed marked variations which are of systematic and taxonomic significance and are reported for the first time. The presence of pith with septum on the petiole of $M$. charantia separates it from the other six species. In M. cabraei petiole, two cell layers of grit cells appear below the epidermis whereas in $M$. cissoides, the brachysclerids interspersed the epidermal cells. The petiolar grit cells are lacking in the other five species; whereas this suggests closer affinity between the two species, their positioning separates them but the presence also distinguishes them from the other species. The occurrence of starch deposits in various tissue layers of the petiole of $M$. multiflora stands it out. The number of vascular bundles present in the petiole of the various species ranges from six to 18 numbers, whereas they are 18 in $M$. multiflora and $M$. angustisepala; 10 in $M$. charantia; $M$. cabraei and $M$. foetida, they are eight in $M$. cissoides and six in $M$. balsamina and could be used in phyolgenetic tree construction. The number of layers of hypodermal sclerenchyma confirms that all species could be put in the same genus as it ranges between one to seven layers in all species examined. The presence or absence of hypodermal parenchyma could be used as distinguishing character amongst the species and strengthens the vascular bundle quantitative evidence in phyolgenetic tree construction. Stem anatomical display show that cortical parenchyma could be a distinguishing feature as there is marked variation in layer thickness amongst the various species. The Sclerenchymatous layer of the cortex connotes closer taxonomic ties amongst the species which could be used to enclose them in the same genus except for M. balsamina where it distinguished the species from others. Whereas in other species, the layers are between six to nine cell layers, in M. balsamina it is between 15 to 17 cell layers thick standing it out taxonomically. Grit cells are present in $M$. cabraei scattered across tissue layers, M. multiflora arranged directly below epidermis and lacking in $M$. cossoides where it occurred in petiole. The nature of epidermal cells suggests taxonomic affinity amongst the species. The present result indicates and strengthens the fact that the species could continue to be treated as same genus but separate as they are as species. It also affirms that the genus belongs to the tribe Cucurbitoideae.

An indented taxonomic (diagnostic) key based on stem and petiole anatomical characters of the Momordica $\mathrm{L}$ species studied in the present work is presented below.

1. Grit/stone cells/sclereids present in either or both stem and petiole anatomical section.

2. Grit/stone cells found only in petiole section

3. Grit/stone cells two layers below the epidermis of petiole section, petiole with 10 bicollateral vascular bundles.

\section{M. cabraei}

3'Grit/stone cell interspersed the epidermis of petiole section, petiole with 8 bicollateral vascular bundle

\section{M. cissoides}

2' Grit cell found below epidermis of the stem anatomical section on the ridge, stem has 20 bicollateral vascular bundle, starch deposits took the place of stone cells in petiole anatomical section.

\section{M. multiflora}

1' Grit cell absent in both stem and petiole anatomical section

4. Both cortical parenchyma and collenchyma absent in stem anatomical section with variations in number of vascular bundles and sclerenchyma thickness.

5. Bicollateral vascular bundle 11 with eight to nine layers of sclerenchyma, pith with

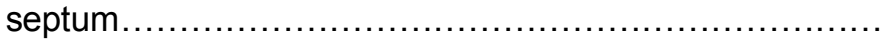
M. angustisepala

5' bicollateral vascular bundle 18 with 15 to 17 layers of sclerenchyma made of cells with thick walls around the ridges

............. M. balsamina.

4' cortical parenchyma and collenchyma present

6. Six sclerenchyma layers

7. 10 bicollateral vascular bundle, stem section having 
hollow

cylinder,

pith

absent

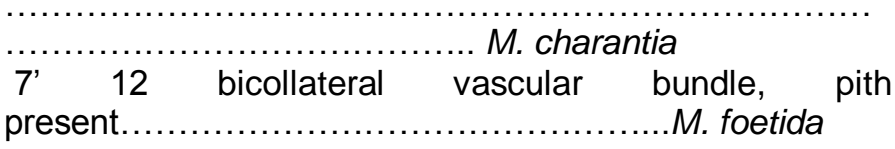

\section{ACKNOWLEDGEMENTS}

The authors are thankful to the technologists at the Advanced Biology Laboratory of Federal University of Agriculture Makurdi, Nigeria and Cytogenetics and Biosystematics Laboratory of Plant Science and Biotechnology laboratory, University of Port Harcourt, Port Harcourt Nigeria.

\section{REFERENCES}

Aguoru CU, Ogaba JO (2010). Ethonobotanical Survey of Anti-Typhoid Plants Amongst The Idoma People of Nigeria. Int. Sci. Res. J. 2:3440.

Aguoru CU, Okoli BE (2008). Seed Coat Anatomy of Momordica L. (Cucurbitaceae) in Parts of Tropical western Africa. Int. J. Trop. Agric. Food Syst. 2(1):29-33.

Dutta AC (2007). Botany for Degree students $6^{\text {th }}$ Edition Oxford University Press. Oxford $708 \mathrm{pp}$.

Edeoga HO, Okoli BE (1997). Anatomy and Systematics in the Costus afar C lucanusianus complex (Costaceae) Acta. Phylatax. Geo. Bot. 48:151-158.

Edeoga HO, Okoli BE (2001). Midrib Anatomy and Systematics in Dioscorea L (Dioscoreaceae). J. Econ. Tax. Bot. 19:191-195.

Hutchinson J, Dalziel JM (1954). Flora of West Tropical Africa Vol. I, Part I. Crown Agents London.
Jeffrey C (1964). Key to the Cucurbitaceae of West Tropical Africa with a guide to localities and little know species. J. W. Afr. Sci. Assoc. 9:79- 97.

Jeffrey C (1980). A review of Cucurbitaceae. Bot. J. Linn. Soc. 81:2332479.

Mbagwu FN, Edeoga HO (2006). Leaf Anatomy of some Nigerian species of Vigna Savi ( Leguminosea - Papilionoideae) Med. Well Onl. Agric. J. 1(1):5-7

Ndukwu BC (1988). Morphological, anatomical and cytological studies on some lesser known Nigerian Cucurbits. M.Sc. Thesis, University of Port Harcourt. Nigeria.

Nwachukwu CU, Mbagwu FN (2007). Leaf Anatomy of eight species of Indigofera L. Med. Well Onl. Agric. J. 2 (1):149-154.

Okoli BE (1984). Wild and Cultivated Cucurbits in Nigeria. Econ. Bot. 38(5):350-357.

Purseglove JW (1968). Tropical Crops, Dicotyledons Vol. I Longman London.

Singh D, Dattan ASR (1980). Programme and abstract, conference on the Biology and Chemistry of Cucurbitaceae. August 3-6: Cornell University Ithaca, USA.

Tsuchiya T, Gupta PK (1991). Chromosome Engineering in plants. In Genetics, breeding evolution, Part B: Fort Collins, Colorado pp.191195.

Uno G, Storey R, Moore R (2001). Principles of Botany $1^{\text {st }}$ ed. McGrawHill Higher Education. New York USA p. 552.

Vaughan JG (1970). The Structure and Utilization of Oil Seeds, Chapman and Hall, London p. 409. 